http://dx.doi.org/10.18778/1508-1117.24.04

\author{
Katarzyna Zajda
}

\title{
RURAL TERRITORY AND SOCIAL INNOVATIONS
}

\begin{abstract}
The aim of the article is to characterize the potential of rural territorial systems concerning possible implementation of social innovations. The article focuses on the specificity of functioning of institutions and organizations essential for the creation of local systems of social innovations, i.e. local authorities, non-governmental organizations (including local action groups) and local entrepreneurs. It compares the level of social trust mutually expressed by local authorities, non-governmental organizations and local entrepreneurs associated in local action groups from Lubuskie, Opolskie and Zachodniopomorskie voivodeships (located within so-called Western and Northern Territories) and Małopolskie voivodeship (located within the historical region of Galicia). The analyses concern the results of the research project titled "Structure and determinants of social capital in local action groups" financed from the resources of the National Science Centre (agreement no. 6996/B/ $H 03 / 2011 / 40$ ), developed in 2011-2013. The conclusions refer to the criteria of division of territorial systems into those with better and poorer opportunities for the creation of local systems of social innovations and the importance of their location in historical regions of Poland for cooperation between institutions and organizations which may potentially become their elements.
\end{abstract}

Key words Territory, social innovations, rural areas, regional innovation system theory.

\section{Introduction}

Due to the diversity and complexity of problems existing in local communities, the bottom-up approach is necessary to solve them. The use of the community-led local development in the 2014-2020 programming perspective is supposed to foster the participation of local communities in solving problems which affect them, among others by stimulating their innovativeness, including the encouragement to implement social innovations (Polityka spójności na lata 2014-2020..., 2014, p. 3).

Social innovations are just one type of innovations; apart from them, K. Najder-Stefaniak identifies technological, organizational and ecological innovations (2010, p. 14-15). They are defined as: "the development and implementation of 
new ideas (products, services and models) to meet social needs and create new social relationships or collaborations" (Guide to Social Innovation 2013, p. 6). Their goal is to eliminate or solve social problems by activating the potentials of the communities in which the problems occur, with their active participation.

As S. Oosterlynck emphasizes, it is obvious that the process of social innovations is territorially embedded, and any changes occurring thanks to their implementation must be analyzed in the socio-territorial context (Moulaert 2000; cf. Crouch et al. 2004; Klein 2009; Oosterlynck et al. 2013). It is so because actions which are innovative in a given environment may not be innovative in another territory (cf. Moulaert 2009).

In the regional innovation system theory, it is assumed that regions' but also larger or smaller territories' innovation capacities are determined by the entities which form the system working for innovations, i.e. those that work in this field and are related to other institutions and organizations operating for the same purpose. The relations between entities are determined among others by the resources they have. As pointed out by A. Nowakowska, territories' ability to implement innovations is not a simple total of such abilities of individual entities being part of the innovation system. This value appears as a result of synergy effect, which may, but does not have to, occur as a consequence of cooperation of various entities engaged in implementing innovations (Nowakowska 2009, p. 21).

The number and diversity of entities forming local and regional innovation systems differs depending on the specificity of the territory. Both in rural and in urban areas, there are non-governmental organizations, economy entities, as well as public institutions interested in solving social problems. However, these territorial communities differ in the number and diversity of the entities.

\section{Methodology of own study}

The aim of the author's own research was to characterize the potential of rural territorial systems for possible implementation of social innovations. It focused on the specificity of functioning of institutions and organizations essential for the creation of local systems of social innovations, i.e. local authorities, non-governmental organizations (including local action groups) and local entrepreneurs. It involved the comparison of the level of social trust mutually expressed by local authorities, non-governmental organizations and local entrepreneurs associated in local action groups from Lubuskie, Opolskie and Zachodniopomorskie voivodeships (located within so-called Western and Northern Territories) and Małopolskie voivodeship ${ }^{1}$ (located within the historical region of Galicia). The research

${ }^{1}$ The analyses concerned the results of the research project titled "Structure and determinants of social capital in local action groups" financed from the resources of the National Science Centre (agreement no. 6996/B/H03/2011/40), developed in 2011-2013. 
involved the question whether the level of trust expressed by the representatives of institutions and organizations potentially engaged in the implementation of social innovations associated in local action groups located within Lubuskie, Opolskie and Zachodniopomorskie voivodeships (in the historical region of Western and Northern Territories) would be lower than that of people associated in local action groups located in Małopolska (in the historical region of Galicia).

All the LAGs which were taken into account while forming the survey sample realized scheme 2 of the LEADER+ Pilot Programme. The analysis covered 9 organisations from Lubuskie, Opolskie and Zachodniopomorskie and 11 from Małopolskie .

The research was conducted as an individual survey (addressed to members, partners of local action groups operating in the selected voivodeships). The research involved 103 respondents from organizations located in Lubuskie, Opolskie and Zachodniopomorskie voivodeships and 183 from local action groups located in Małopolska. 30.1\% of the respondents from LAGs located within the historical Western and Northern Territories were representatives of the public sector, 17.5\%, of the economic sector, and $46.6 \%$, of the social sector. As for the respondents from LAGs located within the historical region of Galicia, the public sector was represented by $20.8 \%$, the economic sector by $22 \%$, and the social one, by $57.1 \%$.

\section{The entities involved in rural local systems of social innovations}

Fewer non-governmental organizations operate in Polish rural areas than in towns; they are also newer. J. Przewłocka estimates that there are about 80 thousand of them (2012, p. 4). Rural NGOs associate fewer members, are poorer and based on unpaid work of their members more than the urban ones. Approximately $14 \%$ of rural associations and foundations employ their staff, compared to $28 \%$ of organizations seated in towns (Herbst 2008, p. 50-54; Bednarek-Szczepańska 2011). The lower financial and human potential of rural associations and foundations results in their mostly local activity. These characteristics of the rural sector of non-governmental organizations may lead to its being more oriented at activities aimed at maintaining its activity than introducing social innovations, which - just like any other - involve some risk (see Goldsmith et al. 2010).

Local action groups are a specific type of rural non-governmental organizations. They were established in Poland as a result of implementation of the LEADER approach in the European Union. Each local action group is made up of representatives of the public sector (among others, local authorities, commune cultural centers, welfare work centers and libraries), the social sector (non-governmental organizations, farmers' wives' associations and voluntary fire brigades) and the economic one (entrepreneurs and farmers) and supports an area of between one and more than ten rural and urban-rural communes (except towns 
with more than 20 thousand residents). In the programming period 2007-2013 in 16 voivodeships 335 local action groups existed (see PSDB 2012, p. 17). They are a specific type of rural non-governmental organizations not only because they are made up of representatives of three sectors (see Bukraba-Rylska 2011; Zajda 2011, 2014; Psyk-Piotrowska et al. 2013), but also because of their high professionalization and economization level (see Zajda, Kretek-Kamińska 2013). They were established as a result of implementation of the LEADER approach in the European Union, using the principle of innovativeness defined as implementing projects which are new on a given territory, both as regards the issues tackled and the proposed way of solving the existing problems (Budzich-Szukała 2008, p. 119). In literature of the subject it is highlighted that local action groups may have a special impact on the implementation of social innovations in rural areas (Dargan, Shucksmith 2008; Implementation of the LEADER approach 2010, p. 73-75; see Granberg, Andersson, Kovách 2015).

Public institutions are perceived (not only in rural areas but also in towns) as innovative entities inclined to introduce changes, especially radical ones (cf. Drewe et al. 2008; Lane et al. 2009). As revealed by a study carried out by A. Tuziak within Podkarpackie Voivodeship (both in rural and urban communes), the awareness of the specificity of innovations and their variety among representatives of public administration is rather low. Very often they cannot define what innovation is, and if they try to do so, they identify it with something new, with introducing new or modernized solutions, improvement and development of existing products (Tuziak 2013, p. 246).

The contribution of public institutions to the innovative development of local systems may be assessed in a different way. S. Oosterlynck observes: "Some approaches concentrate mostly on the negative effects of public intervention as undermining the autonomy of civic associations or limiting the free competition of actors, ideas and solutions. Others highlight more decisively the possibility of synergies (and the conditions to realize them) among public institutions, private organizations and civil society" (2013, p. 24-26).

Depending on the assessment of a certain public institution regarding its potential in supporting the implementation of innovations, it is treated as a more or less significant element of local innovation systems.

Family micro enterprises employing few (up to 9) people are dominant in rural areas (Kłodziński 2011, p. 20). The level of development of entrepreneurship varies greatly from commune to commune. M. Kłodziński observes: "The situation is worst in poorly developing communes, where self-governments and communal offices have very low awareness of the situation and problems of local firms and they only remember about entrepreneurs when they need financial support for a communal festivity, sports event or school trip" (2011, p. 25). Many of them fail due to the competition on the local market (Kłodziński 2010, p. 21). The focus on 
survival instead of development (see Łapiński 2010; Kłodziński 2014, p. 109) is not good either for implementing innovations or for supporting entities that would like to implement them. This diagnosis does not mean that rural entrepreneurs are never part of local innovation systems and do not work for social innovations. Engaging in this process often does not require either financial or organizational expenditure. It is especially true for the entrepreneurs who (often unconsciously) implement the idea of corporate social responsibility, which encourages them to apply ethics when trying to meet the needs of local community members (also those that are not the recipients of the services or products offered by them), respecting natural environment resources (cf. Bromley 1991; Carroll 1993; Zuzek 2013, p. 284, 287; Ratajczak, Wołoszyn 2014, p. 128).

\section{Relationships between entities of local social innovation systems in rural areas}

The relations between entities which may potentially form local social innovation systems are sometimes complicated.

Polish researchers often view negatively the paternalistic system existing between local authorities and the social sector, in which local authorities have a privileged position. T. Kasprzak and M. Jewdokimow observe that quantitative analyses of studies carried out periodically by the Klon/Jawor Association show that self-government institutions are the key partners for half of Polish organizations, and in rural areas self-government is often the only source of financing the actions taken $(2008$, p. 50). This does not promote independence and autonomy of those entities. Literature of the subject also points out that out of non-governmental organizations, authorities give priority to voluntary fire brigades, sports clubs and farmers' wives' associations, perceiving other organizations as potential bases for new political leaders, namely their rivals (see Trutkowski, Mandes 2005; Furmankiewicz 2013; Zajda 2013).

The relationships between the members and partners of local action groups are also thoroughly described. In this context, especially one problem is pointed out: the process of their municipalization, or colonization by self-governmental authorities that attempt (mostly informally) to dominate their works, for example the authorities influencing the composition of the governing and decision-making body of a local action group by recommending a person associated with local authorities as a representative of the social or economic sector (Knieć 2010, p. 65; Halamska, Michalska, Śpiewak 2010). Moreover, it is very difficult to encourage entrepreneurs to participate in these organizations. Their activity is often only formal (their membership is only recorded in documents), and the sham nature of the membership in LAGs is proved e.g. by the low attendance at general meetings of members / partners, only held once or twice a year (Zajda 2011, p. 126). 
As M. Kłodziński points out: "All enterprises operate in so-called suspension between the local community, i.e. the recipients of services, who evaluate their activity and determine the social standing in the commune, and the local authorities whose policies may have a very important impact on the development of the enterprise" (2010, p. 21). He observes that local authorities approach the duty to support entrepreneurship, imposed by the Act of 2 July 2004 on freedom of economic activity, in very different ways (Kłodziński 2011, p. 25). For example they rarely contact entrepreneurs or invite them for consultations, and sometimes entrepreneurs are treated in offices as intruders, unwanted (demanding) guests, exceptionally pragmatic - only interested in cooperation that can bring them profits, preferably within a short period of time (Zajda 2013). Analyzing the Podkarpacie region, A. Tuziak points out that the support provided to entrepreneurs by public administration entities usually involves indirect actions, such as improving the condition of technical infrastructure, promoting the values of the commune, or making the work of self-government administration more efficient. Much less frequently they involve activities such as applying tax breaks, lowering other charges, or providing plots with services connected (Tuziak 2013, p. 257-258). I. Kropsz and B. Kutkowska, recapitulating the results of research carried out in Dolny Śląsk region, point out: "The entrepreneurs have clear expectations concerning the activity of institutional environment of rural business. It comes down to tax breaks, training sessions, consultancy, reduction of bureaucracy in acquiring EU funds, and first of all the officials' attitude to their activities" (2008, p. 102).

Interactions between entrepreneurs and non-governmental organizations are generally difficult in Polish rural communities. The former, mainly looking for opportunities to sell their products and services in the local community, usually cooperate with NGOs (e.g. by sponsoring their activity) when they can see the possibility to increase their competitiveness. The latter perceive small and medium-sized rural entrepreneurs from the perspective of tough market competition, not as philanthropists willing to support local NGOs disinterestedly (Zajda 2013).

\section{Regional differences in trust among local authorities, non-governmental organizations and entrepreneurs associated in local action groups}

The factors which lead to diverse opportunities of territorial systems in terms of forming local systems of social innovations include not only the saturation of the systems with entities that may become their elements but also the specific relations between them resulting from socio-cultural conditions. As A. Peisert and T. Kotnarowski emphasize, "the region where a certain commune is located is the carrier of a specific bundle of cultural characteristics influencing the level of civic participation" (2012, p. 250). The specificity of the region may not only affect the level of civic participation of its inhabitants but also the norms and values they approve or the level of their social trust. 
Certain specific features of the Western and Northern Territories are pointed out in literature of the subject. After 1945, the region was settled by people from more densely populated regions (central and southern parts of Poland), and people displaced from the east. The economic situation of the region depended, on the one hand, on the resources available for settlers in the settled lands, adopted from the displaced German population (high urbanization level, complex infrastructure, and a specific culture of "entrepreneurship"). On the other hand, it was affected by the policy of the authorities (nationalization of enterprises, creating cooperative farms, dividing large land properties into small farms). A specific community developed in the area under consideration, made up of "rootless", poorly integrated people, without common traditions and identity or strong mechanisms of social control. On the one hand, it led (and still leads) to intensifying pathological behaviors (crime, carelessness about the common good, atomization), and on the other hand it promoted "(...) exceeding the previous boundaries of the community (openness, mobility) or new behaviors in the economic sphere (creativity, innovativeness)" (Działek 2011, p. 63). The analyses of this area emphasize its negative image as a "land inhabited by 'orphans of communism' led by the nearly archetypical figures of former State Agricultural Farm workers (...) devoid of any social capital, a set of poorly educated, dependent individuals taking everything for granted and expressing many other negative qualities" (Zarycki 2004, p. 60). However, it is also pointed out that "the decreasing role of the Church and other pre-modern structures and institutions made the communities in this part of the world most similar to the contemporary secularized Western communities. Despite many weaknesses they have greater organizational abilities reflected in the work of non-governmental organizations" (Zarycki 2004, p. 60).

The area of historical Galicia is characterized by the social and civil activity of its residents. Thanks to the fact that it received autonomy after the division of the Habsburg monarchy and the creation of Austria-Hungary, "the range of social, national and political freedom was incomparably higher here than in the other partitions. There was great emphasis on education. A huge number of officials, teachers, politicians and artists of the future Second Polish Republic originated from this area. But on the other hand (...) the region was economically backward, because it was northern Czech Republic that played the role of the industrial center of the Imperial-Royal monarchy. Galicia was a poor territory with very low income. The social structure of the region was archaic, involving deeply rooted class divisions, antagonisms between peasants, townspeople and landowners. Hence, the Galician rural areas were really backward. (...) Small agricultural farms were dominant. (...) But on the other hand, the existing inequalities and tensions combined with political freedom resulted in an intensive development of political movements and associations whose goal was to fight backwardness. (...) At the same time, the historically rooted rural self-government (unlike in other regions, really 
independent) and urban self-government had a great importance" (Peisert, Kotnarowski 2012, p. 254-255). The specific features of the discussed region were the high level of local integration, "the sense of territorial belonging", religiousness and Church affiliation, resulting in the dominance of social activity in the area, mostly based on binding capital (Bartkowski 2003; Działek 2011).

Local action groups may be the discussion forum for representatives of public, social and economic sectors, allowing the exchange of experiences, confronting one's own viewpoints with others', and overcoming stereotypes and prejudice. They may promote the formation of social trust between the representatives of the three sectors. This trust can vary depending on the regional socio-cultural context, because rural areas are the environment of lasting cultural traditions (Bednarek-Szczepańska 2011, p. 220-226; Wójcik 2013, p. 41). Therefore, the level of trust among the members of local action groups from the Western and Northern Territories and the area of historical Galicia was verified in the study.

The respondents associated in local action groups located within the area of historical Western and Northern Territories had greatest trust in the representatives of the social sector (declared by $82.9 \%$ of them), and lowest in entrepreneurs, although the difference between the participants declaring trust in entrepreneurs and those declaring trust in local authorities was not considerable: $59.1 \%$ of the respondents trusted local authorities, while $57.4 \%$ of them trusted entrepreneurs.

Local authorities were mostly trusted by the representatives of the public sector, while local non-governmental organizations, by the representatives of the social one. As for local entrepreneurs, for a change, they were mostly trusted by the representatives, not of the economic sector, but the public one (see tab. 1).

The declarations of respondents from local action groups located in the area of historical Western and Northern Territories indicate that cooperation within these organizations contributed to the increase of the level of trust among the representatives of the three sectors. Public sector representatives in LAGs were trusted by $76.2 \%$ of the participants, those from the social sector, by $93.9 \%$, and the representatives of the economic sector associated in LAGs, by $85.9 \%$ of the participants (actually, more participants declared trust in entrepreneurs associated in LAGs than in the representatives of non-governmental organizations who belonged to those organizations).

Trust in local authorities associated in LAGs was most often declared by the representatives of the public sector; representatives of non-governmental organizations were most often trusted by representatives of the public and social sectors, and trust in local entrepreneurs (belonging to LAGs) was most often declared by representatives of the economic sector (see tab. 2).

A slightly lower percentage of respondents from LAGs located within the historical region of Galicia (as compared to those working in LAGs from the area of historical Western and Northern Territories) declared trust in local authorities, 
Table 1

Trust of respondents associated in LAGs from the area of historical Western and Northern Territories in local authorities, local entrepreneurs and non-governmental organizations

\begin{tabular}{|c|c|c|c|c|c|c|c|c|c|c|c|c|}
\hline \multirow{4}{*}{$\begin{array}{l}\text { Respondents' } \\
\text { sector }\end{array}$} & \multicolumn{12}{|c|}{ Respondents' trust toward } \\
\hline & \multicolumn{4}{|c|}{ Local government } & \multicolumn{4}{|c|}{$\mathrm{NGO}$} & \multicolumn{4}{|c|}{ Local entrepreneurs } \\
\hline & \multicolumn{2}{|c|}{ yes } & \multicolumn{2}{|c|}{ no } & \multicolumn{2}{|c|}{ yes } & \multicolumn{2}{|c|}{ no } & \multicolumn{2}{|c|}{ yes } & \multicolumn{2}{|c|}{ no } \\
\hline & $\mathrm{N}$ & $\%$ & $\mathrm{~N}$ & $\%$ & $\mathrm{~N}$ & $\%$ & $\mathrm{~N}$ & $\%$ & $\mathrm{~N}$ & $\%$ & $\mathrm{~N}$ & $\%$ \\
\hline Public & 16 & 80.0 & 4 & 20.0 & 14 & 82.4 & 3 & 17.6 & 7 & 63.6 & 4 & 36.4 \\
\hline Economic & 5 & 55.6 & 4 & 44.4 & 10 & 76.9 & 3 & 23.1 & 5 & 55.6 & 4 & 44.4 \\
\hline Social & 15 & 48.4 & 16 & 51.6 & 30 & 88.2 & 4 & 11.8 & 13 & 59.1 & 9 & 40.9 \\
\hline
\end{tabular}

Source: own research.

Table 2

Trust of respondents associated in LAGs from the area of historical Western and Northern Territories in representatives of local authorities, local entrepreneurs and non-governmental organizations associated in LAGs

\begin{tabular}{|l|c|c|c|c|c|c|c|c|c|c|c|c|c|}
\hline \multirow{3}{*}{$\begin{array}{c}\text { Respondents' } \\
\text { sector }\end{array}$} & \multicolumn{4}{|c|}{$\begin{array}{c}\text { Respondents' trust toward } \\
\text { in LAG }\end{array}$} & \multicolumn{2}{|c|}{ yes } & \multicolumn{2}{|c|}{ no } & \multicolumn{3}{c|}{ NGO in LAG } & \multicolumn{3}{c|}{$\begin{array}{c}\text { Local entrepreneurs } \\
\text { in LAG }\end{array}$} \\
\cline { 2 - 17 } & $\mathrm{N}$ & $\%$ & $\mathrm{~N}$ & $\%$ & $\mathrm{~N}$ & $\%$ & $\mathrm{~N}$ & $\%$ & $\mathrm{~N}$ & $\%$ & $\mathrm{~N}$ & $\%$ \\
\hline Public & 25 & $\mathbf{1 0 0}$ & 0 & 0 & 22 & $\mathbf{9 5 . 7}$ & 1 & 4.3 & 20 & 87.0 & 3 & 13.0 \\
\hline Economic & 9 & 60.0 & 6 & 40.0 & 13 & 92.9 & 1 & 7.1 & 15 & $\mathbf{9 3 . 8}$ & 1 & 6.3 \\
\hline Social & 27 & 69.2 & 12 & 30.8 & 38 & 95.0 & 2 & 5.0 & 28 & 82.4 & 6 & 17.6 \\
\hline
\end{tabular}

Source: own research.

although the difference was not considerable $-54.3 \%$ of the total number of respondents from those organizations, compared to $59.2 \%$ of respondents declaring trust in local authorities in the case of LAGs from Western and Northern Territories).

Besides, fewer participants (71.8\%) from LAGs operating in historical Galicia declared trust in local non-governmental organizations and fewer (45.8\%) pointed out they trusted local entrepreneurs - whereas in the case of respondents from LAGs operating in the historical Western and Northern Territories, the percentage of those declaring trust in local NGOs and entrepreneurs was $82.9 \%$ and $57.4 \%$, respectively. Local authorities, just like non-governmental organizations, were most often trusted by representatives of the public sector (see tab. 3). 
Trust of respondents associated in LAGs from the area of historical Galicia in local authorities, local entrepreneurs and non-governmental organizations

\begin{tabular}{|c|c|c|c|c|c|c|c|c|c|c|c|c|}
\hline \multirow{4}{*}{$\begin{array}{l}\text { Respondents' } \\
\text { sector }\end{array}$} & \multicolumn{12}{|c|}{ Respondents' trust toward } \\
\hline & \multicolumn{4}{|c|}{ Local governments } & \multicolumn{4}{|c|}{$\mathrm{NGO}$} & \multicolumn{4}{|c|}{ Local entrepreneurship } \\
\hline & \multicolumn{2}{|c|}{ yes } & \multicolumn{2}{|c|}{ no } & \multicolumn{2}{|c|}{ yes } & \multicolumn{2}{|c|}{ no } & \multicolumn{2}{|c|}{ yes } & \multicolumn{2}{|c|}{ no } \\
\hline & $\mathrm{N}$ & $\%$ & $\mathrm{~N}$ & $\%$ & $\mathrm{~N}$ & $\%$ & $\mathrm{~N}$ & $\%$ & $\mathrm{~N}$ & $\%$ & $\mathrm{~N}$ & $\%$ \\
\hline Public & 19 & 70.4 & 8 & 29.6 & 17 & 73.9 & 6 & 26.1 & 11 & 64.7 & 6 & 35.3 \\
\hline Economic & 12 & 44.4 & 15 & 55.6 & 18 & 69.2 & 8 & 30.8 & 7 & 41.2 & 10 & 58.8 \\
\hline Social & 32 & 50.8 & 31 & 49.2 & 46 & 69.7 & 20 & 30.3 & 17 & 41.5 & 24 & 58.5 \\
\hline
\end{tabular}

Source: own research.

The representatives of local authorities, local non-governmental organizations and entrepreneurs who were members of local action groups were trusted more by the respondents belonging to organizations from the area of historical Galicia. Perhaps direct contacts influenced the change in attitude towards them (see tab. 4). Trust in local authorities associated in LAGs and in entrepreneurs was most often declared by representatives of the public sector; whereas representatives of non-governmental organizations associated in LAGs were mostly trusted by the respondents from the social sector.

Table 4

Trust of respondents associated in LAGs from the area of historical Galicia in representatives of local authorities, local entrepreneurs and non-governmental organizations associated in LAGs

\begin{tabular}{|c|c|c|c|c|c|c|c|c|c|c|c|c|}
\hline \multirow{4}{*}{$\begin{array}{l}\text { Respondents' } \\
\text { sector }\end{array}$} & \multicolumn{12}{|c|}{ Respondents' trust toward } \\
\hline & \multicolumn{4}{|c|}{$\begin{array}{l}\text { Local governments } \\
\text { in LAG }\end{array}$} & \multicolumn{4}{|c|}{$\mathrm{NGO}$ in $\mathrm{LAG}$} & \multicolumn{4}{|c|}{$\begin{array}{l}\text { Local entrepreneurs } \\
\text { in LAG }\end{array}$} \\
\hline & \multicolumn{2}{|c|}{ yes } & \multicolumn{2}{|c|}{ no } & \multicolumn{2}{|c|}{ yes } & \multicolumn{2}{|c|}{ no } & \multicolumn{2}{|c|}{ yes } & \multicolumn{2}{|c|}{ no } \\
\hline & $\mathrm{N}$ & $\%$ & $\mathrm{~N}$ & $\%$ & $\mathrm{~N}$ & $\%$ & $\mathrm{~N}$ & $\%$ & $\mathrm{~N}$ & $\%$ & $\mathrm{~N}$ & $\%$ \\
\hline Public & 23 & 88.5 & 3 & 11.5 & 18 & 81.8 & 4 & 18.2 & 17 & 73.9 & 6 & 26.1 \\
\hline Economic & 16 & 64.0 & 9 & 36.0 & 15 & 65.2 & 8 & 34.8 & 15 & 65.2 & 8 & 34.8 \\
\hline Social & 43 & 67.2 & 21 & 32.8 & 58 & 84.1 & 11 & 15.9 & 45 & 72.6 & 17 & 27.4 \\
\hline
\end{tabular}

Source: own research.

\section{Conclusions}

Opportunities for implementing social innovations depend on the characteristics of the territory. The resources of rural areas limit their possibilities of creating and implementing technological innovations, but they still provide the opportunities 
for creating and carrying out social innovations. Evaluating them, we can identify the territories which manifest the ability to create local innovation systems and those with low potential in this regard. In the light of the presented reflections, we can list two basic reasons for this. The first of them is the lack of institutions interested in implementing social innovations, i.e. non-governmental organizations and local entrepreneurs that would be inclined to participate in the process. Territorial self-government cannot be the only element of the local social innovation system. The other reason is the relationships between institutions and organizations which work for social innovations separately but are unable to cooperate in a consistent and lasting manner, and as a result to form a local system of social innovations.

The advantage of rural areas is local action groups, i.e. organizations providing a plane of cooperation for all the entities that are potentially interested in implementing social innovations. It is worth noticing that the implementation of the LEADER approach in a given territory is regarded as a social innovation. One of its goals is to overcome the problem of low level of cooperation between the representatives of public institutions and non-governmental organizations for multifunctional and sustainable rural development.

The results of own research presented here show that representatives of local authorities, entrepreneurs and non-governmental organizations associated in these structures (in comparison to more anonymous and unfamiliar local authorities, non-governmental organizations and entrepreneurs which are outside them) are more often trusted, and the trust is a prerequisite of long-term cooperation, also with social innovations in view. Representatives of local authorities are most trustful towards the representatives of the three sectors, which may result from their experience in contacts with local non-governmental organizations and entrepreneurs.

The results of the research did not confirm greater willingness to cooperate among the representatives of the public, social and economic sectors from local action groups located within the historical region of Galicia (which would result from the declared mutual trust of their representatives). Greater trust in representatives of the three sectors (and thus greater cooperation potential) was observed in participants from Lubuskie, Opolskie and Zachodniopomorskie voivodeships (the historical Western and Northern Territories), which corresponds to the complex character of that area presented in the literature of the subject - on the one hand, described from the perspective of atomization, weak social bonds and the lack of sense of identity, and on the other hand, from the perspective of social activity which is an attempt to overcome these social phenomena. Thus, the study follows the trend of analyses highlighting the complexity of relations between selected social capital resources (in this case, social trust) and the social and civic traditions of historical regions of Poland. However, when interpreting 
the findings, it has to be remembered that the regions are not homogeneous, and the influence of their past on their present conditions can never be reduced to the analysis of a limited system of variables.

\section{BIBLIOGRAPHY}

Bartkowski J., 2003, Tradycja i polityka. Wpływ tradycji kulturowych polskich regionów na wspótczesne zachowania społeczne i polityczne, Wydawnictwo Akademickie „Żak”, Warszawa.

Bednarek-Szczepańska M., 2011, Organizacje pozarzadowe na obszarach pozametropolitarnych na przykładzie wybranych regionów, [w:] Wesołowska M. (red.), Wiejskie obszary peryferyjne - uwarunkowania i czynniki aktywizacji, „Studia Obszarów Wiejskich.”, 26, s. 216-230.

Bromley D.W., 1991, Environment and Economy: Property Rights and Public Policy, Blackwell, New York.

Budzich-Szukała U., 2008, Program LEADER w Polsce - sposób na aktywizację wsi, [w:] Wilkin J., Nurzyńska I. (red.), Polska wieś 2008. Raport o stanie wsi, Fundacja na Rzecz Rozwoju Polskiego Rolnictwa, Warszawa.

Bukraba-Rylska I. (red.), 2011, Między interwencja a interakcja. Lokalne grupy działania w społecznościach wiejskich, Wydawnictwo Naukowe Scholar, Warszawa.

Carroll A.B., 1993, Business and Society: Ethice and Stakeholder Management, College Division South - Western Publishing Co., Ohio.

Chambon J.-L., David A., Devevey J.-M., 1982, Les innovations socials, Presses Universitaires de France, Paris.

Crouch C., Le Gales P., Trigilia C., Voelzkow H., 2004, Changing Governance of Local Economies: Responses of European Local Production Systems, Oxford University Press, Oxford.

Dargan L., Shucksmith M., 2008, LEADER and Innovation, „Sociologia Ruralis”, 48(3), s. $274-291$.

Drewe P., 2008, The URBAN Initiative or the EU as Social Innovator?, [in:] Drewe P., Klein J.-L., Hulsbergen E. (eds.), The Challenge of Social Innovation in Urban Revitalization, Techne Press, Amsterdam, p. 183-196.

Działek J., 2011, Kapitał społeczny jako czynnik rozwoju gospodarczego w skali regionalnej i lokalnej w Polsce, Wydawnictwo UJ, Kraków.

Furmankiewicz M., 2013, Wspótrzadzenie czy ukryta dominacja sektora publicznego? Koncepcja governance $w$ praktyce lokalnych grup działania, „Studia Regionalne i Lokalne", 1(51), s. 71-89.

Goldsmith S., Georges G., Burke T.G., 2010, The Power of Social Innovation. How Civic Entrepreneurs Ignite Community Networks for Good, Jossey-Bass, San Francisco.

Granberg L., Andersson K., Kovách I. (eds.), 2015, Evaluating the European Approach to Rural Development. Grass-roots Experiences of the LEADER Programme, Ashgate, Unitided Kingdom.

Guide to Social Innovation 2013, European Commision, Brussels.

Halamska M., Michalska S., Śpiewak R., 2010, LEADER w Polsce. Drogi implementacji programu, „Wieś i Rolnictwo”, 4(149), s. 104-119. 
Herbst J., 2008, Inny trzeci sektor. Organizacje pozarzadowe na terenach wiejskich, [w:] Halamska M. (red.), Wiejskie organizacje pozarzadowe, IRWiR PAN, Warszawa.

Implementation of the LEADER approach. Special Report No 5, 2010, European Court of Auditors, Luxemburg.

Kasprzak T., Jewdokimow M., 2008, Administracja publiczna a przedsiębiorstwa ekonomii społecznej, [w:] Przedsiębiorstwo ekonomii społecznej w środowisku lokalnym, Stowarzyszenie Klon/Jawor Warszawa, s. 49-76.

Klein J.-L., 2009, Introduction: Territorial development and social innovation, „Canadian Journal of Regional Science", 1, p. 3-12.

Kłodziński M., 2010, Mikroprzedsiębiorczość na obszarach wiejskich, „Wieś i Rolnictwo", 2(147), s. 20-34.

Kłodziński M., 2011, Kondycja ekonomiczna sektora małych i średnich przedsiębiorstw $w$ Polsce w latach 2008-2009 a problemy rozwoju przedsiębiorczości wiejskiej, „Wieś i Rolnictwo", 2(151), s. 9-29.

Kłodziński M., 2014, Przedsiębiorczość pozarolnicza na wsi w procesie wielofunkcyjnego rozwoju obszarów wiejskich, „Wieś i Rolnictwo”, 1(162), s. 97-112.

Knieć W., 2010, Partnerstwa lokalne w Polsce - kondycja, struktura, wyzwania. Raport badawczy, Fundacja Partnerstwo dla Środowiska, Kraków-Toruń.

Kropsz I., Kutkowska B., 2008, Stan przedsiębiorczości na obszarach wiejskich Dolnego Śląska, „Wieś i Rolnictwo”, 1(138), s. 88-103.

Lane D., Van der Leeuw S., Pumain D., West G., 2009, Complexity Perspectives in Innovation and Social Change, Springer, Berlin.

Łapiński J., 2010, Działalność innowacyjna przedsiębiorstw innowacyjnych $w$ Polsce, [w:] Zadura-Lichota P. (red.), Innowacyjność 2010, PARP, Warszawa, s. 7-68.

Moulaert F., 2000, Globalization and integrated area development in European cities, Oxford University Press, Oxford.

Moulaert F., 2009, Social innovation: Institutionally embedded, territorially (re)produced, [in:] Maccallum D., Moulaert F., Hillier J., Vicari-Haddock S. (eds.), Social innovation and territorial development, Ashgate Publishing, Surrey.

Najder-Stefaniak K., 2010, Wstęp do innowatyki, Wydawnictwo SGGW, Warszawa.

Nowakowska A., 2009, Regionalny kontekst procesów innowacji, [w:] Nowakowska A. (red.), Budowanie zdolności innowacyjnych regionów, Wydawnictwo UŁ, Łódź.

Oosterlynck, S., Kazepov Y., Novy A., Cools P., Barberis E., Wukovitsch F., Sarius T., Leubolt B., 2013, The butterfly and the elephant: local social innovation, the welfare state and new poverty dynamics. ImPRovE Discussion Paper No. 13/03, Herman Deleeck Centre for Social Policy, University of Antwerp, Antwerp.

Peisert A., Kotnarowski T., 2012, Tradycje obywatelskie polskich regionów a partycypacja obywatelska, [w:] Olech A. (red.), Dyktat czy uczestnictwo? Diagnoza partycypacji publicznej w Polsce, Instytut Spraw Publicznych, Warszawa.

Polityka spójności na lata 2014-2020. Rozwój lokalny kierowany przez społeczność. Arkusz informacyjny, Komisja Europejska, marzec 2014.

Przewłocka J., 2012, Polskie organizacje pozarządowe 2012, Stowarzyszenie Klon/Jawor, Warszawa.

PSDB 2012, Ocena funkcjonowania LGD realizujacych LSR w ramach PROW 20072013, maszynopis niepublikowany, Warszawa. 
Psyk-Piotrowska E., Zajda K., Kretek-Kamińska A., Walczak-Duraj D, 2013, Struktura i uwarunkowania kapitatu społecznego lokalnych grup działania, Wydawnictwo UŁ, Łódź.

Ratajczak M., Wołoszyn J., 2014, Działania na rzecz społeczeństwa w zakresie Corporate Social Responsibility na przyktadzie przedsiębiorstw agrobiznesu, ,Journal of Agribusiness and Rural Development", 4(34), s. 127-135.

Trutkowski C., Mandes S., 2005, Kapitał społeczny w matych miastach, Wydawnictwo Naukowe Scholar, Warszawa.

Tuziak A., 2013, Innowacyjność w endogenicznym rozwoju regionu peryferyjnego. Studium socjologiczne, Wydawnictwo Naukowe Scholar, Warszawa.

Wójcik M., 2013, Wieś 2050 - refleksje na temat przyszłości wsi polskiej ze szczególnym uwzględnieniem regionu łódzkiego, [w:] Bański J. (red.), Polska wieś w perspektywie dtugookresowej-ujęcie regionalne, ,Studia Obszarów Wiejskich”, 31, s. 39-51.

Zajda K., 2011, Nowe formy kapitału społecznego wsi. Studium przypadku lokalnych grup działania z województwa łódzkiego, Wydawnictwo UŁ, Łódź.

Zajda K., 2013, Władza lokalna, organizacje pozarządowe i przedsiębiorcy - wspótdziatanie na rzecz rozwoju wsi w powiecie radomszczańskim, „Samorząd Terytorialny”, 3(267), s. 10-20.

Zajda K., 2014, Problems of Functioning of Polish Local Action Groups from the Perspective of the Social Capital Concept, ,Eastern European Countryside”, 20, p. 73-98.

Zajda K., Kretek-Kamińska A., 2013, Professionalisation and economization of rural NGOs and the activity of their members, ,Journal of Agribusiness and Rural Development", 1(27), p. 249-260.

Zarycki T., 2004, Kapitał społeczny a trzy polskie drogi do nowoczesności, „Kultura i Społeczeństwo", 48, s. 45-65.

Zuzek D., 2013, Społeczna odpowiedzialność biznesu - wyzwania dla matych i średnich przedsiębiorstw $w$ odniesieniu do ich konkurencyjności, „Journal of Agribusiness and Rural Development", 2(28), s. 281-289.

\section{WIEJSKIE UKŁADY TERYTORIALNE I INNOWACJE SPOLECZNE}

Zarys treści Celem artykułu jest scharakteryzowanie potencjału wiejskich układów terytorialnych w zakresie możliwości wdrażania innowacji społecznych. Przedmiotem rozważań jest specyfika funkcjonowania instytucji i organizacji kluczowych dla tworzenia lokalnych systemów innowacji społecznych, tj. władz lokalnych, organizacji pozarządowych (w tym lokalnych grup działania) oraz lokalnych przedsiębiorców. Porównany został poziom zaufania społecznego, jakim obdarzają się władze lokalne, organizacje pozarządowe i lokalni przedsiębiorcy zrzeszeni w lokalnych grupach działania z terenu województw lubuskiego, opolskiego i zachodniopomorskiego (należących do tzw. Ziem Zachodnich i Północnych) oraz województwa małopolskiego (należącego do historycznego obszaru Galicji). Źródłem analiz są badania zrealizowane w ramach projektu pt.: „Struktura i uwarunkowania kapitału społecznego lokalnych grup działania" wdrażanego w latach 2011-2013 (finansowanego ze środków Narodowego Centrum Nauki). Wnioski 
dotyczą kryteriów podziału układów terytorialnych na te, które dysponują większymi i mniejszymi szansami w zakresie kształtowania lokalnych systemów innowacji społecznych oraz znaczenia ich ulokowania w historycznych regionach Polski dla kształtowania współpracy między instytucjami i organizacjami potencjalnie wchodzącymi w ich skład.

Słowa kluczowe Terytorium, innowacje społeczne, wieś, teoria regionalnych systemów innowacji, historyczne regiony Polski.

Dr Katarzyna Zajda Katedra Socjologii Wsi i Miasta Wydział Ekonomiczno-Socjologiczny, Uniwersytet Łódzki 